\title{
Assessment of Indonesia's Future Renewable Energy Plan: A Meta-Analysis of Biofuel Energy Return on Investment (EROI)
}

\author{
Wiraditma Prananta *(D) and Ida Kubiszewski (D) \\ Crawford School of Public Policy, The Australian National University, Canberra 2601, Australia; \\ ida.kub@gmail.com \\ * Correspondence: wiraditma.prananta@gmail.com; Tel.: +62-822-8108-7575
}

Citation: Prananta, W.; Kubiszewski,

I. Assessment of Indonesia's Future

Renewable Energy Plan: A

Meta-Analysis of Biofuel Energy

Return on Investment (EROI).

Energies 2021, 14, 2803. https://

doi.org/10.3390/en14102803

Academic Editor: Pierre Desrochers

Received: 22 March 2021

Accepted: 10 May 2021

Published: 13 May 2021

Publisher's Note: MDPI stays neutral with regard to jurisdictional claims in published maps and institutional affiliations.

Copyright: (C) 2021 by the authors Licensee MDPI, Basel, Switzerland. This article is an open access article distributed under the terms and conditions of the Creative Commons Attribution (CC BY) license (https:// creativecommons.org/licenses/by/ $4.0 /)$.

\begin{abstract}
In early 2020, Indonesia implemented the biodiesel 30 (B30) program as an initiative to reduce Indonesia's dependency on fossil fuels and to protect Indonesia's palm oil market. However, palm oil has received international criticism due to its association with harmful environmental externalities. This paper analysed whether an investment in palm oil-based biofuel (POBB) provides Indonesia with the ability to achieve its environmental and financial goals. In this research, we performed a meta-analysis on biofuel energy return on investment (EROI) by examining 44 biofuel projects using ten types of biofuel feedstocks from 13 countries between 1995 and 2016. Results showed an average EROI of 3.92 and 3.22 for POBB and other biomass-based biofuels (OBBB), respectively. This shows that if only energy inputs and outputs are considered, biofuels provide a positive energy return. However, biofuels, including those from palm oil, produce externalities especially during land preparation and land restoration. We also compared these EROI biofuel results with other renewable energy sources and further analysed the implications for renewable energies to meet society's energy demands in the future. Results showed that biofuel gives the lowest EROI compared to other renewable energy sources. Its EROI of 3.92, while positive, has been categorised as "not feasible for development". If Indonesia plans to continue with its biofuel program, some major improvements will be necessary.
\end{abstract}

Keywords: palm oil; biofuel; EROI; Indonesia; Indonesian B30 program; renewable energy

\section{Introduction}

As impacts of climate change increase it is critical to choose appropriate technologies that move us closer to our $2{ }^{\circ} \mathrm{C}$ target. Bioenergy with carbon capture and storage (BECCS) provides one promising carbon capture method [1]. Utilising that captured carbon to produce chemicals, materials, and transportation fuels may provide a greater financial incentive than storing the carbon [2]. Another method, negative emissions technology (NET), requires biomass to be converted, through a thermochemical process of pyrolysis, into either biochar, pyrolysis gas, or bio-oil [3]. Biochar especially is receiving significant scrutiny as a potential solution to carbon capture [4].

However, these carbon capture methods are still within the development stages [5]. Using proven technologies is essential to slow down and mitigate climate change. Currently, two of the primary industries emitting $\mathrm{CO}_{2}$ are the coal and oil industries. A shift away from combusting fossil fuels would provide us with an opportunity and additional time to develop negative emissions technologies.

To this effect, global efforts to increase renewable energy development and use have progressed over the past decade, and this is also true in Indonesia. Renewable and sustainable energy development addresses concerns regarding energy security, fossil fuel dependency, and a commitment to achieve a climate change mitigation strategy [6]. By the first quarter of 2020, the share of global renewable energy supply reached $28 \%[7,8]$. Wind power, solar PV, hydropower, and bioenergy are the most developed renewable powers globally $[7,8]$. 
As an emerging country and one of the world's biggest energy consumers, the Indonesian energy sector contributes $35 \%\left(508.1 \mathrm{MtCO}_{2} \mathrm{e}\right)$ of the country's total greenhouse gas (GHG) emissions $[9,10]$. In its Nationally Determined Contribution (NDC), Indonesia pledged to bring its emissions down by $29 \%$ (or $41 \%$ with international assistance) by 2030 , where promoting an energy supply mix from new and renewable energy (NRE) has been stated as one of the strategies to achieve the target [11].

Among some renewable energy sources available for development, Indonesia is projected to rely on bioenergy ( $51 \%$ of the total energy consumption) by 2030 [11]. This bioenergy is derived from oil palm trees, which produce oily fruit that can be harvested approximately every six months. Each hectare of oil palm yields around $4000 \mathrm{~kg}$ of palm oil per harvesting. In 2018, Indonesia produced 40.57 million tonnes of palm oil, utilizing 6.78 million ha of land [12]. The majority of this palm oil is exported around the world. Global demand has tripled over the past 18 years, with India importing 9.18 million tonnes per year [13].

Meanwhile, the consumption of other renewable energy sources, such as hydropower, geothermal, solar PV, and wind power, is to remain low by $2030(14 \%, 9 \%, 8 \%$, and $1 \%$, respectively) [10]. Furthermore, in early 2020, the Government of Indonesia (GoI) launched a B30 biofuel program, a mandatory biofuel blending policy requiring 30 percent fuel produced from palm oil. The GoI stated that the B30 program will support Indonesia in achieving its target to reduce its greenhouse gas emissions and dependency on fossil energy use [14].

Palm oil-based biofuel (POBB) has become a favourable source of energy in Indonesia. Indonesia is the world's leading palm oil producer and is developing a large-scale industry around it, particularly for electricity and transportation $[15,16]$. Oil palm trees produce a higher energy yield in comparison to other biomass-based biofuels (OBBB) (e.g., soybean, rapeseed, and sunflower) [17-19]. However, debates and international criticisms exist around palm oil expansion and development. The expansion and cultivation method of oil palm trees has triggered deforestation, peat fires (including regional tensions from the haze with Singapore, Malaysia, and Thailand), biodiversity loss, hydrological changes, problems with indigenous communities, and other social conflicts [19-23]. Purely considering carbon emissions, palm oil as a bioenergy may emit as much, if not more, greenhouse gasses than fossil fuels [24].

Techniques exist to evaluate the viability of energy sources, including life cycle analysis (LCA), cost-benefit analysis (CBA), net energy analysis, and other approaches using economic or emissions analysis. Investment in biofuels requires an understanding of how much energy the biofuel yields relative to the energy required to produce it [25]. This assessment technique is called energy return on investment (EROI) and aims to examine the ratio of gross energy required directly and indirectly to produce and deliver energy to society [26-28].

This paper analysed the EROI of biofuels and considered possible externalities and environmental impacts of biofuels-particularly palm oil. Analysing the EROI of biofuels helps clarify whether an investment in POBB provides a positive net energy return to Indonesia to meet its energy demands in the future from renewable sources. This paper further compares the biofuel EROI with other NRE options in Indonesia and discusses Indonesia's NRE policy implications. The goal of this study was to determine whether the Indonesian biofuel plan can meet the target to reduce Indonesia's dependency on fossil fuel and carbon emissions. This study complements existing literature on biofuel energy analysis, particularly in eastern and southern Asia, where the largest producers and consumers of POBB are found [16].

\section{Literature Review}

\subsection{Renewable Energy Development}

The annual growth of global renewable energy production reached $6.5 \%$ between 2010-2019 and exceeded fossil fuel growth, including coal and natural gas, in the same 
period [7]. Various nations, particularly those with developed economies, have begun a transition toward green energies and have commenced building large-scale renewable energy projects. Policies, investment, supports, and incentives from various governments and nongovernmental organisations have become essential instruments to accelerate renewable energy development [29]. Among the options of alternatives energies, solar PV, wind energy, hydropower, and bioenergy are the most widely used sources and have implemented advanced technologies [7,30,31].

Hydropower has become the largest source of renewable energy globally. This energy occupies a $16 \%$ share of electricity supply and 100 Terawatt hours (TWh) of energy produced in 2019 [7]. China, the United States, Brazil, Canada, and India are the top users accounting for half of global hydropower use [7]. Hydropower plays an essential role in clean energy transitions as this energy provides cost-effective and affordable electrical energy production [7,32]. Such benefits also help countries addressing energy security and climate change mitigation issues through diversification of energy from locally and transboundary resources [32]. However, with any transboundary resource like river systems, hydropower can contribute to regional integration or to significant transboundary conflict. Hydropower has led to fostering economic development and political cooperation but has also led to floods, water scarcity, reduced water quality, and mass relocation in downstream countries $[33,34]$.

In 2019 , the global wind energy supply rose by about 150 TWh $(5.2 \%$ of all electricity supply), making it the highest renewable power generated in the year [7]. The United Kingdom, European Union, China, and the United States led in wind power production thanks to large-scale commercial offshore and onshore wind farms [6,7]. China showed the highest wind energy improvement in recent years. Its energy capacity grew from 10 Gigawatts (GW) in 2014 to more than $25 \mathrm{GW}$ in 2019 [6,7].

Solar PV came second as the most generated renewable power in 2019 with energy production reaching $130 \mathrm{TWh}$ globally [7]. Most countries favoured this particular energy as it is not accompanied by the release of harmful gases and particles and produces minimal GHG emissions, making it an ideal source to support climate change mitigation $[29,35]$. Europe is the most solarised continent with nearly $100 \mathrm{GW}$ of installed capacity in 2015, of which the UK, Germany, and France dominated the solar PV market in the continent [29]. Other countries, such as China, Japan, and the United States, are also among the global leader in terms of solar energy consumption [7,29].

In addition, other renewable energies, such as geothermal and marine energy, also show a promising development for the future. Geothermal power is expected to grow by $28 \%$ in 2024 [36]. Indonesia and the Philippines, which possess more than one-third of global geothermal reserves, are expected to develop more geothermal power in the future [37]. While marine energy has great potential, it has not yet been widely developed and has experienced slow growth in recent decades [36,38]. Until 2019, only a few countries, such as the United Kingdom, Canada, Australia, and China, have invested in marine energy with installed capacity ranging from $10 \mathrm{~kW}$ to $1 \mathrm{MW}$ only [38].

Biofuels, unlike the above-mentioned energies that are mainly produced to generate electricity, are generally produced for the transportation sector. This fuel can derive various feedstocks and be subdivided into four generations according to the chemical nature and complexity of biomass: the first generation is derived from vegetable oil, animal fats, sugar, starch-mainly food crops-and produced using conventional methods; the second generation is obtained from nonfood crops and biowastes (e.g., wood, corn stover); the third generation is produced from algae; and the fourth generation is produced from biological waste from plants and animals through a genetically engineered process [39]. Global biofuel production was increased by $8 \%$ in 2019 in major producing countries, even though it had been experiencing a slower growth rate in recent years [7,40]. Biofuels' increasing demand has been recorded in some emerging economies, such as Brazil, China, Indonesia, and Argentina [40]. Several policies, including obligatory blending mandates, preferential taxes, and subsidies, have influenced the increasing demand for biofuels [40]. 
By contrast, biofuel demand fell in the European Union and the United States. In the European Union, biofuel imports are expected to keep decreasing after the Renewable Energy Directive (RED) II that categorises POBB under a high Indirect Land Use Change (ILUC) risk category [40].

\subsection{Renewable Energy Policy in Indonesia}

The National Energy Policy (NEP) in Indonesia is governed under Government Regulation No. 79/2014. Within this regulation, the GoI set a target to increase the NRE use by $23 \%$ in 2025 and $31 \%$ in 2050 [41]. This is as a strategy to achieve its national energy security and reduce fossil fuel dependency [41]. Until 2019, renewables only contributed to $12 \%$ of the installed capacity mix in Indonesia, of which hydropower and geothermal power contributed the most with $5.4 \mathrm{GW}$ and $2.1 \mathrm{GW}$ power installed, respectively [42]. After Indonesia submitted its first NDC in 2016, NRE became an instrument to achieve a climate mitigation and GHG emissions reduction strategy [7].

Furthermore, a year after the GoI enacted the NEP, the Ministry of Energy and Mineral Resources (MEMR) further enacted Ministerial Regulation No. 12/2015 on biofuel supply, utilisation, and trading as an alternative fuel [14]. Under this regulation, the GoI has been expanding its POBB blending program that started with 15\% in 2015 to $30 \%$ in 2020 with a goal to reach a fossil-free biofuel (B100) in 2050 [14]. The MEMR stated that biofuels are essential in reducing Indonesia's dependency on fuel imports and would support the domestic economy [43]. Studies estimate that biofuel will play a significant role in renewable energy consumption in Indonesia, making up half of Indonesia's renewable energy consumption, with $24 \%$ coming from liquid POBB by $2030[10,42]$.

\section{Materials and Methods}

\subsection{Meta-Analysis}

This study performed a meta-analysis on biofuel EROI by examining 44 biofuel projects. This study categorised the biofuel feedstocks according to their biofuel generations (1st and 2nd generation) and their types of feedstock (soybean, corn, palm oil, sunflower, sugarcane, sugar beet, rice straw, rapeseed, jatropha, wood cellulose, and switchgrass). The focus of this study was on POBB, which has not undergone much analysis in Indonesia [44].

\subsection{System Boundaries \\ 3.2.1. EROI Calculations}

The chosen system boundaries of a study have significant impacts on the outcomes of net energy analyses [28]. Hall et al. (2009) analysed that different system boundaries (e.g., the number of stages in the life cycle) used in EROI calculation results in variation in EROI numbers/findings [27]. A common approach to calculating standard EROI (EROIst) is to divide the energy output by the sum of direct (on-site) and indirect (off-site) energy input $[28,45]$. However, this study recognised Hall et al.'s (2014) work on expanding the EROI system boundaries to include the overall gains from fuel production and all cost from obtaining that energy (EROIsoc) [45]. Expanding the energy analysis provides a more comprehensive analysis that considers externalities such as climate change, environmental factors, and social benefits into the calculation $[45,46]$. Using EROIsoc system boundaries will also enable understanding the minimum energy requirements for societies to survive, reproduce, and sustain its activities [45,46].

\subsubsection{Biofuel System Boundaries}

This study adopted Manik and Halog's (2013) system boundaries analysis into biofuel production steps: 1 . land preparation, 2 . agricultural process, 3. mill procession, 4 . conversion to biofuel, 5. use of biofuel, and 6. replanting and pulverisation (see Figure 1). From the implementation of the above's steps, there are four categories of life cycles within the biofuel industry [44]:

- Cradle-to-grave: for studies that include all steps (1-5) of biofuel processing 
- Cradle-to-gate: for studies that begin in step 1 but do not end in step 5

- Gate-to-grave: for studies that do not start in step 1 but end in step 5

- Gate-to-gate: for other studies that do not fulfil the above criteria

\section{System boundaries in biofuel life cycle and data observed}

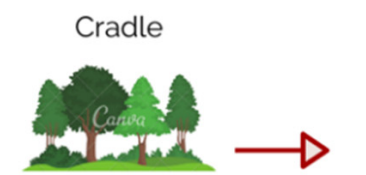

Step 1

Land Preparation

总

Gate

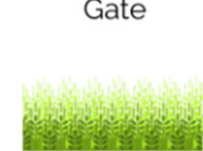

Step 2

Agricultural Process
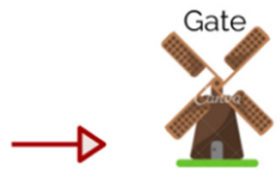

Step 3 Mill Procession

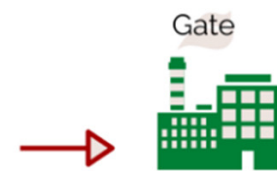

Step 4

Conversion to biofue (Industrial)

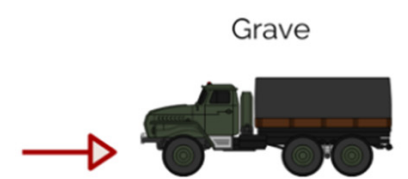

Step 5

Use of Biofuel

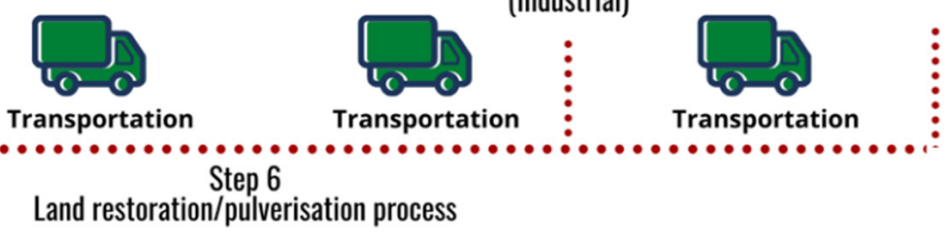

Land restoration/pulverisation process

$\begin{array}{cccccc}\text { Cradle-to-grave } & \text { Cradle-to-gate } & \text { Gate-to-gate } & \text { Gate only }(1 \text { stage }) & \text { Gate-to-Grave } & \text { Cradle-to-Cradle } \\ 0 \% & 6.8 \% & 84.1 \% & 2.3 \% & 6.8 \% & 0 \% \\ & (3 \text { projects }) & (37 \text { projects }) & (1 \text { project }) & (3 \text { projects }) & \end{array}$

Figure 1. Biofuel system boundaries from the data observed. Source: authors.

This research analysed that there is a possibility of adding a 5th category (cradleto-cradle) in the biofuel life cycle. The 5th category involves a process that begins from step 1 but does not end in the "grave" process, it rather forms a cycle that involves land and system restoration/pulverisation and replanting processes. However, it is considered difficult to include the land preparation and land restoration in the EROI calculation due to differences in variables and detecting the origin of the plantation [44].

The figure below shows the system boundaries in the biofuel life cycle from land preparation (step 1) to land restoration/pulverisation (step 6), with the possibility of going back to step 1 (replanting process). From the 44 biofuel datasets observed, most studies used gate-to-gate analysis while only three studies included the land preparation (cradleto-gate) and also three studies used the gate-to-grave process. None of the data observed used full cycle analysis; cradle-to-grave or cradle-to-cradle.

\section{Results}

We performed a meta-analysis of 44 biofuel studies. These studies covered 11 feedstocks in 13 countries across Africa, Asia, Europe, North America, and South America (see Table 1). These 44 studies were performed between 1995 and 2016. Out of these, 29 studies analysed EROI from operational projects while 15 considered conceptual projects.

The results showed that POBB has an average EROIst of $3.92(n=17$, std. dev $=0.98)$ while the OBBB have a slightly lower EROI result of $3.22(n=44$; std. $\mathrm{dev}=2.06)$ (see Table 2). Meanwhile, if biofuel generation was taken into account (see Figure 2.), the results showed an average EROIst of 3.31 and 2.32 for the first- and second-generation biofuels, respectively.

If the EROI was classified according to feedstocks (e.g., crop items, crop residue, and woody materials), results showed the food crop items (soybean, corn, palm oil, rapeseed, sunflower, sugar beet, and sugarcane) had an average EROIst of 3.94, nonfood crops 
(jatropha and switchgrass) had an average EROIst of 2.34, food residue (rice straw) had an EROIst of 3.46, and woody material (wood cellulose) showed an EROIst of 0.64 .

Table 1. Geographical distribution and type of feedstocks reviewed in this study.

\begin{tabular}{|c|c|c|c|}
\hline Region & Country & Type of Feedstocks & Projects \\
\hline \multirow{4}{*}{ Asia } & Thailand & Oil palm, jatropha & 4 \\
\hline & Indonesia & Sugarcane, oil palm & 2 \\
\hline & Japan & Rice straw & 1 \\
\hline & Malaysia & Oil palm, jatropha, rapeseed & 5 \\
\hline \multirow{4}{*}{ Europe } & Italy & Soybean & 1 \\
\hline & Ireland & Rapeseed & 1 \\
\hline & Austria & Sugar beet & 1 \\
\hline & Greece & Soybean & 1 \\
\hline \multirow{3}{*}{ South America } & Brazil & Soybean, oil palm, sugarcane & 10 \\
\hline & Argentina & Soybean & 4 \\
\hline & Colombia & Oil palm & 3 \\
\hline North America & United States & $\begin{array}{l}\text { Corn, switchgrass, soybean, } \\
\text { wood cellulose, sunflower }\end{array}$ & 10 \\
\hline Africa & Cameroon & Oil palm & 1 \\
\hline
\end{tabular}

Table 2. Metadata analysis of biofuel energy.

\begin{tabular}{|c|c|c|c|c|c|c|}
\hline $\begin{array}{c}\text { Type of } \\
\text { Feedstock }\end{array}$ & Authors/Reference & Location & EROIst & $\begin{array}{l}\text { EROIst } \\
\text { Average }\end{array}$ & $\begin{array}{c}\text { System } \\
\text { Boundaries }\end{array}$ & Project \\
\hline \multicolumn{7}{|c|}{ 1st Generation } \\
\hline \multirow{13}{*}{ Soybean } & Sheehan et al. (1998) [49] & United States & 0.81 & \multirow{13}{*}{2.35} & $2,3,4,5$ & $\mathrm{o}$ \\
\hline & Carraretto et al. (2004) [50] & Italy & 2.2 & & $2,3,4,5$ & o \\
\hline & Pimentel and Patzek (2005) [51] & United States & 0.98 & & $2,3,4$ & c \\
\hline & Hill et al. (2006) [52] & United States & 1.92 & & $2,3,4$ & $\mathrm{o}$ \\
\hline & Tsoutsos et al. (2009) [53] & Greece & 1.16 & & $2,3,4$ & $\mathrm{o}$ \\
\hline & Cavalett and Ortega (2010) [54] & Brazil & 2.48 & & $2,3,4$ & $\mathrm{o}$ \\
\hline & Pradhan et al. (2011) [55] & United States & 5.54 & & $2,3,4$ & c \\
\hline & Rocha et al. (2014) [56] & Brazil & 2.88 & & $2,3,4$ & c \\
\hline & Brondani et al. (2015) [57] & Brazil & 3.08 & & $2,3,4$ & c \\
\hline & Piastrellini et al. (2016) [58] & Argentina-a & 1.77 & & $2,3,4$ & $\mathrm{o}$ \\
\hline & Piastrellini et al. (2016) [58] & Argentina-b & 3.1 & & $2,3,4$ & $\mathrm{o}$ \\
\hline & Piastrellini et al. (2016) [58] & Argentina-c & 1.86 & & $2,3,4$ & $\mathrm{o}$ \\
\hline & Piastrellini et al. (2016) [58] & Argentina-d & 2.83 & & $2,3,4$ & $\mathrm{o}$ \\
\hline \multirow{3}{*}{ Corn } & Lorrenz and Morris (1995) [59] & United States & 1.38 & \multirow{3}{*}{1.15} & $2,3,4$ & o \\
\hline & Pimentel and Patzek (2005) [51] & United States & 0.78 & & $2,3,4$ & c \\
\hline & Hill et al. (2006) [52] & United States & 1.28 & & $2,3,4$ & $\mathrm{o}$ \\
\hline
\end{tabular}


Table 2. Cont.

\begin{tabular}{|c|c|c|c|c|c|c|}
\hline $\begin{array}{c}\text { Type of } \\
\text { Feedstock }\end{array}$ & Authors/Reference & Location & EROIst & $\begin{array}{l}\text { EROIst } \\
\text { Average }\end{array}$ & $\begin{array}{c}\text { System } \\
\text { Boundaries }\end{array}$ & Project \\
\hline \multirow{17}{*}{ Palm Oil } & Yusoff and Hansen (2007) [60] & Malaysia & 4.05 & \multirow{17}{*}{3.92} & $1,2,3,4$ & $\mathrm{o}$ \\
\hline & Thamsiriroj and Murphy (2008) [61] & Thailand & 2.64 & & $2,3,4$ & c \\
\hline & Papong et al. (2010) [47] & Thailand & 3.33 & & $2,3,4$ & o \\
\hline & Yee et al. (2009) [62] & Malaysia & 3.53 & & $1,2,3,4$ & $\mathrm{o}$ \\
\hline & Pleanjai and Gheewala (2009) [63] & Thailand & 3.57 & & $2,3,4$ & o \\
\hline & Angarita et al. (2009) [59] & Brazil-a & 3.77 & & $2,3,4$ & o \\
\hline & Angarita et al. (2009) [64] & Brazil-b & 5.72 & & $2,3,4$ & $\mathrm{o}$ \\
\hline & Angarita et al. (2009) [64] & Brazil-c & 4.63 & & $2,3,4$ & $\mathrm{o}$ \\
\hline & Angarita et al. (2009) [64] & Colombia-a & 5.17 & & $2,3,4$ & o \\
\hline & Angarita et al. (2009) [64] & Colombia-b & 4.64 & & $2,3,4$ & o \\
\hline & Angarita et al. (2009) [64] & Colombia-c & 5.01 & & $2,3,4$ & o \\
\hline & Lam et al. (2009) [65] & Malaysia & 2.27 & & $2,3,4$ & c \\
\hline & Kamahara et al. (2010) [48] & Indonesia & 3.63 & & $2,3,4$ & o \\
\hline & Achten et al. (2010) [66] & Cameroon & 2.61 & & $2,3,4$ & c \\
\hline & de Souza et al. (2010) [67] & Brazil & 4.99 & & $2,3,4$ & c \\
\hline & Queiroz et al. (2012) [68] & Brazil-a & 3.41 & & $2,3,4$ & $\mathrm{o}$ \\
\hline & Queiroz et al. (2012) [68] & Brazil-b & 3.59 & & $2,3,4$ & o \\
\hline Sunflower & Pimentel and Patzek (2005) [51] & United States & 0.76 & 0.76 & $2,3,4$ & c \\
\hline \multirow{2}{*}{ Sugarcane } & Agostinho and Siche (2014) [69] & Brazil & 6.7 & \multirow{2}{*}{6.38} & $2,3,4$ & $\mathrm{o}$ \\
\hline & Khatiwalda et al. (2016) [70] & Indonesia & 6.07 & & $2,3,4$ & o \\
\hline Sugar beet & Atlason et al. (2015) [71] & Austria & 11.26 & 11.26 & 2 & o \\
\hline Rice straw & Saga et al. (2010) [72] & Japan & 3.46 & 3.46 & 2,4 & o \\
\hline \multirow{2}{*}{ Rapeseed } & Thamsiriroj and Murphy (2008) [61] & Ireland & 2.19 & \multirow{2}{*}{1.82} & $2,3,4$ & c \\
\hline & Yee et al. (2009) [62] & Malaysia & 1.44 & & $1,2,3,4$ & o \\
\hline \multicolumn{7}{|c|}{ 2nd Generation } \\
\hline \multirow{2}{*}{ Jatropha } & Prueksakorn and Gheewala (2008) [73] & Thailand & 6.03 & \multirow{2}{*}{3.98} & $2,3,4$ & c \\
\hline & Lam et al. (2009) [65] & Malaysia & 1.92 & & $2,3,4$ & c \\
\hline Wood cellulose & Pimentel and Patzek (2005) [51] & United States & 0.64 & 0.64 & $2,3,4$ & c \\
\hline Switchgrass & Pimentel and Patzek (2005) [51] & United States & 0.69 & 0.69 & $2,3,4$ & c \\
\hline
\end{tabular}

Looking at POBB, nearly all the projects observed (16 studies) used gate-to-gate system boundaries, while one included land preparation in the life cycle analysis calculation (cradle-to-gate). Transesterification, or the biofuel production process, requires the highest energy input of all POBB life cycle processes $[47,48]$. The land preparation also requires energy-intensive activities (e.g., land clearance), resulting in higher energy inputs and higher emissions in land preparation (step 1), which is included in the POBB life cycle analysis [44].

Table 2 provides a summary of findings for biofuel EROIst that includes year and project/study location, types of feedstocks used, EROIst results, system boundaries, and types of projects. There are differences in EROI results from other biofuel meta-analysis studies that cite similar sources as coproducts included in this study. 


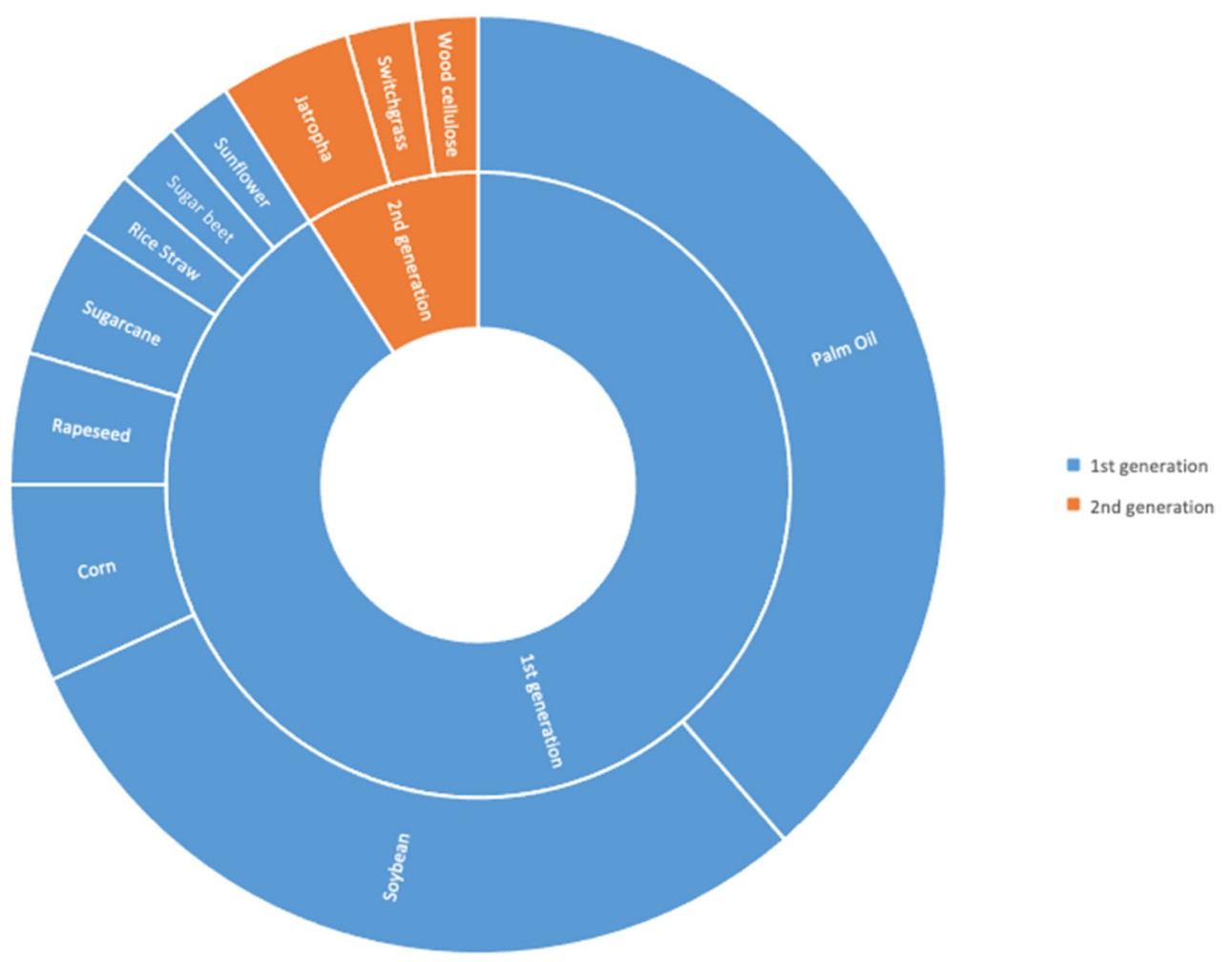

Figure 2. Biofuel projects observed according to biofuel generations and type of feedstocks. Source: authors.

\section{Discussion}

\subsection{Net Energy of Biofuel}

\subsubsection{Biofuel EROIst}

The EROIst results of POBB and OBBB EROIst, 3.92 and 3.22, respectively, showed that investing in biofuel energy brings positive energy return. Table 2 shows that POBB, as the source of Indonesia's biofuel program, provides a higher EROIst than other feedstocks. There are two factors that influence the EROI of POBB. First, oil palm produces a higher yield than other feedstocks. Oil palm is derived from the fresh fruit bunch (FFB) all year round and can be harvested every 10-14 days. This results in an annual average of 3.8 tons per hectare FFB [19]. Second, oil palm coproducts, such as palm kernel oil, could be used for other purposes, such as foods, soaps, and other products.

\subsubsection{Unaccounted Externalities in Biofuel EROIsoc}

Additional energy inputs have not been taken into account in the biofuel (particularly POBB) EROI calculation presented in Table 2. This study considered some potential externalities from the "cradle" to "grave" process that are not accounted for in the EROIst data in Table 2. These externalities may increase the cost to produce biofuel energy and reduce the EROIst-which showed the EROIsoc result.

Within the "cradle" process, the cost and energy associated with land preparationwhich may also include peat and forest fires-is not taken into account. This process involves energy-intensive activities, such as land clearing (i.e., using excavators or burning the land) and soil preparation for agricultural process [44]. Not only does land clearance for agricultural process require a significant amount of energy, but it also contributes to increased GHG emissions. In fact, the land use, land-use change, and forestry (LULUCF) sector is the greatest contributor of GHG emissions in Indonesia (695 MtCO2e, around 48\% of the country's total emissions in 2015) [9,10].

In the "grave" process, a significant amount of energy is required in the replanting and recovering of the degraded land processes after oil palm reaches its productive limit. 
Oil palm requires the digging up of the root mass and pulverisation to thoroughly grind the entire palm into fine pieces [74]. Furthermore, if the plantations are located in peatland areas then there will be additional energy spent to restore the degraded peatland (rewetting process) $[20,75]$.

\subsubsection{Other Environmental and Social Impacts Associated with Oil Palm Industry}

A debate exists in the literature about whether POBB can be categorized as renewable energy that reduces GHG emissions $[19,20,23,75,76]$. Oil palms planted in peatland can trigger an oxidation process in the peat soil and emit up to 1500 tons/ha while the Indonesian peat and forest fires in 2019 emitted 708 million tons of $\mathrm{CO}_{2}$ (almost double the emissions of Brazilian Amazon forest fires in the same year) [19-23,76]. Furthermore, the haze from peat and forest fires often generates transboundary haze pollutions and raises tensions among the Indonesian neighbouring countries, such as Singapore, Malaysia, and Thailand [77]. Although the Indonesian government has set a moratorium on new oil palm plantations in the peatland and forested areas, this policy is only targeting major oil palm companies. Smallholders, who contribute to $45 \%$ of the national palm oil production, do not necessarily comply [20]. Other potential environmental and social impacts associated with oil palm industries are land conflicts, ecosystem services and biodiversity loss, and hydrological impacts [19,75].

On the other hand, some studies have developed scenarios for oil palm that show a minimum, if not positive, emission outcome $[1,75,78]$. First, if oil palm plantations are planted on degraded land, this could reduce net GHG emission [75]. Second, developing new varieties of oil palm could intensify production, producing more yield without needing to clear new plantation areas [78]. Third, implementing bioenergy with carbon capture and storage (BECCS) technologies during the energy transition period provides one promising carbon capture method [1].

\subsection{Comparison to Other Renewable Energy Sources}

This study compared the results of biofuel EROI with other NREs that are feasible in Indonesia. The results showed that POBB $(E R O I=3.92)$ and OBBB $(E R O I=3.22)$ have the least net energy return and a relatively low production lifetime ( 25 years) in comparison to other NRE sources. Table 3 shows that wind energy (EROI: 34.3; lifetime: 20 years), natural gas (41.7; 35 years), hydropower (22.4; 100 years), solar PV (21.5; 30 years), and geothermal energy (20.9; 40 years) all have higher EROI and longer life spans than POBB or OBBB.

Table 3. EROI, lifetime, and category of other new and renewable energy (NRE) sources.

\begin{tabular}{|c|c|c|c|c|c|c|c|}
\hline No & Type of NRE & $\begin{array}{l}\text { Operational/ } \\
\text { Conceptual }\end{array}$ & $\begin{array}{c}\text { EROI } \\
\text { (Range) }\end{array}$ & $\begin{array}{c}\text { EROI } \\
\text { (Average) }\end{array}$ & Category * & $\begin{array}{l}\text { Lifetime } \\
\text { (Year) }\end{array}$ & Author/Reference No. \\
\hline 1 & Wind power & $\mathrm{O}+\mathrm{C}$ & $6.5-57.7$ & 34.3 & No Risk & 20 & Walmsley \& Atkins, 2017 [79] \\
\hline 2 & Natural Gas & $\mathrm{O}+\mathrm{C}$ & 41.7 & 41.7 & No Risk & 35 & Walmsley et al., 2018 [80] \\
\hline 3 & Hydropower & $\mathrm{O}+\mathrm{C}$ & $2.4-38.2$ & 22.4 & No Risk & 100 & Walmsley et al., 2018 [80] \\
\hline 4 & Solar PV & $\mathrm{O}+\mathrm{C}$ & $8.7-34.2$ & 21.5 & No Risk & 30 & Bhandari et al., 2015 [81] \\
\hline 5 & Geothermal & $\mathrm{o}$ & $9.5-32.4$ & 20.9 & No Risk & 40 & Atlason \& Unnthorsson, 2013 [82] \\
\hline
\end{tabular}

\subsection{Minimum EROI for Renewable Energy to Support Society}

Much of the literature on net energy analysis focuses on surpassing the "break-even point" (EROI of 1:1). This means that if the net energy returned is greater than the energy invested, then the project "should be done" [27]. However, EROI is not only about delivering "positive" energy but is also linked (directly and indirectly) to an average citizen's ability to achieve wellbeing [83]. Therefore, a minimum EROI should exist for energy sources 
(along with considering its environmental and social impacts) that allows for societies to survive, reproduce, and sustain their activities.

Table 4. EROI for renewable energy categories (source: authors, amended from Capellán-Pérez et al., 2019 [46]).

\begin{tabular}{cc}
\hline EROIst & Category \\
\hline$>15$ & No risk \\
\hline $10-15$ & Low risk \\
\hline $5-10$ & Dangerous \\
\hline $4-5$ & Very dangerous \\
\hline $2-3$ & Not feasible \\
\hline
\end{tabular}

Some studies suggest that a minimum EROIst of the system should be around 10-15:1 to sustain societies $[27,46,84]$. Lambert et al. (2014) suggested the EROI has to be over 20:1 [83]. This minimum number was proposed not only to meet society's basic needs (e.g., food, shelter, and clothing), but also to support such things as modern healthcare, education, and the arts [83]. Capellán-Pérez et al. (2019) further provided some EROI classifications for renewable energy to meet societal needs in the future (at least by 2060), which were as follows [46]:

With the average EROI results of 3.92 for POBB and 3.22 for OBBB, it shows that all biofuel products do not meet the minimum standard to sustain society's growing energy demands. Thus, by following the Capellán-Pérez et al.'s (2019) categories above, overall biofuel energies (including palm oil) are not feasible for mass investment. Furthermore, it is essential to note that the EROI of POBB may be lower than 3.92 as there are some unaccounted externalities within the EROI calculations.

On the other hand, wind power, natural gas, hydropower, solar PV, and geothermal energy all show positive EROI results. These NREs surpass the minimum EROI requirement to sustain society (either using above 10-15:1 and/or above 20:1 EROI criteria), making them part of the "no risk" category. The implication is that if a country invests in any one of these NREs they will be able to support the energy demands for society. An NRE should not only support society's basic needs (e.g., food, shelter, and clothing) but also support large-scale industries, modern facilities (e.g., healthcare and education), and other secondary and tertiary energy demands. Furthermore, a higher EROI and an energy type's ability to meet societal demands implies that the energy may reduce dependency on fossil fuels.

\subsection{Policy Implications}

\subsubsection{Barriers to Invest in Other Renewable Energies in Indonesia}

From the EROIst assessment presented above, it is evident that biofuel is not feasible for investment as it does not support enough energy for society. Furthermore, if the EROI calculation considers some externalities (using EROIsoc analysis), the actual EROI of POBB may be lower than 3.92. As a result, investing in oil palm-based biofuel will not give significant energy benefits long-term.

The EU's plan to phase out imports of biofuel feedstocks that risk land-use change (including palm oil) by 2030 is also accelerating Indonesia's strategy to find alternative markets for its palm oil products. The Indonesian Palm Oil Association (IPOA) reported that the palm oil industry contributes to $2.46 \%$ of Indonesian GDP and employs 7.8 million farmers and workers in the industry [85]. As of 2018, ownership of the 12.76 million ha of palm plantations in Indonesia is with major oil palm companies (6.36 million ha) while smallholder farmers own 5.81 million ha $(45.53 \%)$ and the state-owned agricultural company owns $4.62 \%$ of the plantations [86]. Excessive palm oil supply would reduce its global price, which would inevitably affect millions of palm oil smallholders and farmers in Indonesia. 
Therefore, utilising domestic production of palm oil within the domestic market would counteract the constraints from the international market [19].

Furthermore, this study found that taking palm oil's net energy analysis into account in Indonesia's RNE policy is essential to avoid the investment trap [87] in said policy. In the short term, investing in palm oil biofuel seems to be profitable and may save the country's economy from losing its palm oil market. However, since the energy does not offer a significant return to society, prioritising biofuel in the NRE policy may not be feasible for investment in the long term. Therefore, it requires further analysis and study comparing the benefits received from palm oil-based biofuel energy in the short- and long-term period.

\subsubsection{Renewable Energy Policy for the Future}

POBB is projected to dominate the portion of NREs (24\%) in Indonesia by 2030 [83]. By contrast, other NRE sources that provide more energy output are only predicted to be a small portion of overall renewable energy use by 2030. The contribution of other RNEs in 2030 would be as follows: hydropower $(14 \%)$, solar PV (8\%), wind energy $(1 \%)$, and geothermal energy (9\%) [88]. This paper suggests diversifying RNE investment into the RNE sources that have higher EROI numbers to gain more energy return that can fulfil society's energy needs. Diversifying energy investments would provide higher energy output and accommodate society's needs both in the present and the future.

However, noting that that palm oil's role is inevitable in supporting Indonesia's economy and millions of smallholders, continuing the B30 project is essential. Some studies have suggested to intensify palm oil production to increase yield and energy output $[78,89]$. The intensification process may increase the yield by up to 18 tonnes FFB/ha annually (from an average of 3.8 to 6 tonnes FFB/ha/year) [19,78]. Saleh et al. (2019) reported that there is around 500,000 ha of oil palm area in 11 provinces that could potentially run the intensification program in the areas that meet the criteria of productivity, soil and biophysics conditions, and plantations' proximity to mills [89]. Furthermore, Kamahara and colleagues (2010), who studied palm oil biofuel EROI in Indonesia, reported that production intensification and energy improvement would increase the EROIst 7.3-8.0 [48]. Apart from intensification, continuing the existing moratorium policy—or possibly making the policy permanent-to avoid new oil palm plantations in the peatlands or forested areas would also reduce the externalities that contribute to high energy inputs [9,78].

Policies can also be implemented to reduce negative externalities. Prohibiting the burning of peatlands would reduce greenhouse gas emissions significantly [90,91]. Using carbon capture and storage technologies throughout the POBB production process could also mitigate carbon emissions [92]. Development in precombustion, postcombustion, and oxyfuel combustion could provide a solution for a form of bioenergy with carbon capture and storage (BECCS) mitigating climate change [93,94]. This would require strong policy support from the GoI but could be a long-term strategy for storing the captured $\mathrm{CO}_{2}$.

\section{Conclusions}

This study analysed Indonesia's POBB renewable energy plan under the B30 program that provides Indonesia the ability to achieve its environmental and financial goals. The analysis started with reviewing literature published between 1995 and 2016 on the energy return on investment (EROI) from biofuel energy projects. The results showed that POBB, the feedstock chosen by the Indonesian government, has an average EROI of 3.92 while the OBBB have an average EROI of 3.22. The result implies that if only energy input and output are considered, biofuels will give positive net energy. However, biofuels, especially from palm oil, produce externalities from the input processes (e.g., land preparation, land restoration, and the refining system), resulting in net energy output reduction.

This study further compared the biofuels' EROI with other NRE sources, then extended the analysis by taking into account a minimum EROI required to sustain society. The results put the biofuels' EROI, either POBB or OBBB, into the category of "not feasible for investment". By contrast, other NRE sources, such as wind power (EROI 34.3), natural gas 
(41.7), hydropower (22.4), solar PV (21.5), and geothermal energy (20.9) were categorised as "no risk" and "feasible for investment". However, this study acknowledged that changes in international palm oil markets have urged policymakers to find an alternative market for palm oil, including consumption in the domestic market. We recommend policymakers diversify investments to other NREs that offer a higher net energy return to avoid the palm oil investment trap and to sustain Indonesia's energy demands. Furthermore, this study also found that some solutions, such as palm oil intensification and avoiding the externalities, may also increase palm oil biofuel's net energy return.

Further study needs to be undertaken to fully assess the environmental and social externalities of palm oil. Ecosystem service valuation could provide one means of determining the true value of biofuels derived from palm oil. It would allow for a more systematic comparison of the costs and benefits for Indonesia's future NRE strategy. Opportunity costs of the land can also be assessed when analysing the feasibility and attractiveness of palm oil production. For example, the long-term carbon sequestration of natural forests.

Currently, there is also a lack of POBB studies performing life cycle analyses or EROI assessments, particularly in major producing countries. As global biofuel production and demands increase, expanding the literature with a harmonized methodology would allow for a more robust meta-analysis.

Author Contributions: Conceptualisation, W.P. and I.K.; Data curation, W.P.; Formal analysis, W.P.; Investigation, W.P.; Methodology, W.P. and I.K.; Project administration, W.P.; Resources, W.P.; Software, W.P.; Supervision, I.K.; Validation, W.P.; Visualization, W.P.; Writing—original draft, W.P.; Writing-review \& editing, W.P. and I.K. All authors have read and agreed to the published version of the manuscript.

Funding: This research received no external funding.

Institutional Review Board Statement: Not applicable.

Informed Consent Statement: Not applicable.

Data Availability Statement: Data is contained within the article.

Acknowledgments: This research was conducted as part of a course at the Crawford School of Public Policy at The Australian National University. The author would like to thank Sayuri Ichikawa for providing constructive comments on this paper.

Conflicts of Interest: The authors declare no conflict of interest.

\section{References}

1. Stavrakas, V.; Spyridaki, N.-A.; Flamos, A. Striving towards the Deployment of Bio-Energy with Carbon Capture and Storage (BECCS): A Review of Research Priorities and Assessment Needs. Sustainability 2018, 10, 2206. [CrossRef]

2. Zhang, Z.; Pan, S.-Y.; Li, H.; Cai, J.; Olabi, A.G.; Anthony, E.J.; Manovic, V. Recent Advances in Carbon Dioxide Utilization. Renew. Sustain. Energy Rev. 2020, 125, 109799. [CrossRef]

3. Yang, Q.; Zhou, H.; Bartocci, P.; Fantozzi, F.; Mašek, O.; Agblevor, F.A.; Wei, Z.; Yang, H.; Chen, H.; Lu, X.; et al. Prospective Contributions of Biomass Pyrolysis to China's 2050 Carbon Reduction and Renewable Energy Goals. Nat. Commun. 2021, 12, 1698. [CrossRef] [PubMed]

4. Fawzy, S.; Osman, A.I.; Yang, H.; Doran, J.; Rooney, D.W. Industrial Biochar Systems for Atmospheric Carbon Removal: A Review. Environ. Chem. Lett. 2021. [CrossRef]

5. Lau, H.C.; Ramakrishna, S.; Zhang, K.; Radhamani, A.V. The Role of Carbon Capture and Storage in the Energy Transition. Energy Fuels 2021, 35, 7364-7386. [CrossRef]

6. Oh, K.-Y.; Nam, W.; Ryu, M.S.; Kim, J.-Y.; Epureanu, B.I. A Review of Foundations of Offshore Wind Energy Convertors: Current Status and Future Perspectives. Renew. Sustain. Energy Rev. 2018, 88, 16-36. [CrossRef]

7. International Energy Agency. Global Energy Review 2019: The Latest Trends in Energy and Emissions in 2019; OECD: Paris, France, 2020; ISBN 9-7892-6449-5852.

8. International Energy Agency. Global Energy Review 2020: The Impacts of the Covid-19 Crisis on Global Energy Demand and CO 2 Emissions; International Energy Agency: Paris, France, 2021.

9. Wijaya, A.; Chrysolite, H.; Ge, M.; Wibowo, C.K.; Pradana, A.; Utami, A.F.; Austin, K. How Can Indonesia Achieve Its Climate Change Mitigation Goal? An Analysis of Potential Emissions Reductions from Energy and Land-Use Policies; Working Paper; World Resources Institute Indonesia: Jakarta, Indonesia, 2017. 
10. International Renewable Energy Agency. Renewable Energy Prospects: Indonesia; International Renewable Energy Agency: Abu Dhabi, Unites Arab Emirates, 2017; ISBN 9-7892-9511-1196.

11. Republic of Indonesia. First Nationally Determined Contribution: Republic of Indonesia; Republic of Indonesia: Jakarta, Indonesia, 2016.

12. Ritchie, H. Palm Oil. Our World in Data. 2019. Available online: https:// ourworldindata.org/palm-oil (accessed on 1 May 2021).

13. FAO. Food Balance Sheets (FBS); Food and Agricultural Organization of the United Nations: 2020. Available online: http: //www.fao.org/faostat/en/?data (accessed on 1 May 2021).

14. Ministry of Energy and Mineral Resources of the Republic of Indonesia. Ministerial Regulation No. 12 Year 2015 Concerning the Third Amendment on Ministerial Decree No 32 Year 2008 Concerning the Supply, Utilisation, and Trade System of Biofuels as Other Fuels; Ministry of Energy and Mineral Resources of the Republic of Indonesia: Jakarta, Indonesia, 2021.

15. Ministry of Energy and Mineral Resources of the Republic of Indonesia. Bioenergy, The Most Complete Renewable Energy. Available online: http:/ / ebtke.esdm.go.id/post/2020/03/06/2497/bioenergi.energi.terbarukan.paling.komplitlangen (accessed on 9 June 2020).

16. Zahan, K.; Kano, M. Biodiesel Production from Palm Oil, Its By-Products, and Mill Effluent: A Review. Energies 2018, 11, 2132. [CrossRef]

17. Barcelos, E.; Rios, S.d.A.; Cunha, R.N.V.; Lopes, R.; Motoike, S.Y.; Babiychuk, E.; Skirycz, A.; Kushnir, S. Oil Palm Natural Diversity and the Potential for Yield Improvement. Front. Plant Sci. 2015, 6, 190. [CrossRef]

18. Rival, A.; Levang, P. Palms of Controversies: Oil Palm and Development Challenges; Center for International Forestry Research (CIFOR): Bogor, Indonesia, 2014; ISBN 9-7860-2150-4413.

19. Pacheco, P.; Gnych, S.; Dermawan, A.; Komarudin, H.; Okarda, B. The Palm Oil Global Value Chain: Implications for Economic Growth and Socialand Environmental Sustainability; Center for International Forestry Research (CIFOR): Bogor, Indonesia, 2017.

20. Barthel, M.; Jennings, S.; Schreiber, W.; Sheane, R.; Royston, S.; Fry, J.; Khor, Y.L.; McGill, J. Study on the Environmental Impact of Palm Oil Consumption and on Existing Sustainability Standards; EU Publications: Luxembourg, 2018.

21. Comte, I.; Colin, F.; Whalen, J.K.; Grünberger, O.; Caliman, J.-P. Chapter Three: Agricultural Practices in Oil Palm Plantations and Their Impact on Hydrological Changes, Nutrient Fluxes and Water Quality in Indonesia. Adv. Agron. 2012, 116, 71-124. [CrossRef]

22. Pendrill, F.; Persson, U.M.; Godar, J.; Kastner, T. Deforestation Displaced: Trade in Forest-Risk Commodities and the Prospects for a Global Forest Transition. Environ. Res. Lett. 2019, 14, 055003. [CrossRef]

23. Cooper, H.V.; Evers, S.; Aplin, P.; Crout, N.; Dahalan, M.P.B.; Sjogersten, S. Greenhouse Gas Emissions Resulting from Conversion of Peat Swamp Forest to Oil Palm Plantation. Nat. Commun. 2020, 11, 407. [CrossRef]

24. Meijide, A.; de la Rua, C.; Guillaume, T.; Röll, A.; Hassler, E.; Stiegler, C.; Tjoa, A.; June, T.; Corre, M.D.; Veldkamp, E.; et al. Measured Greenhouse Gas Budgets Challenge Emission Savings from Palm-Oil Biodiesel. Nat. Commun. 2020, 11, 1089. [CrossRef]

25. Garza, E.L. Life cycle assessment: The energy return on invested of Biodiesel. In Bioenergy; Dahiya, A., Ed.; Academic Press: Cambridge, UK, 2014; ISBN 9-7801-2408-1208.

26. Cleveland, C.J.; Costanza, R.; Hall, C.A.S.; Kaufmann, R. Energy and the U.S. Economy: A Biophysical Perspective. Science 1984, 225, 890-897. [CrossRef] [PubMed]

27. Hall, C.; Balogh, S.; Murphy, D. What Is the Minimum EROI That a Sustainable Society Must Have? Energies 2009, 2, 25-47. [CrossRef]

28. Kubiszewski, I.; Cleveland, C.J.; Endres, P.K. Meta-Analysis of Net Energy Return for Wind Power Systems. Renew. Energy 2010, 35, 218-225. [CrossRef]

29. Kabir, E.; Kumar, P.; Kumar, S.; Adelodun, A.A.; Kim, K.-H. Solar Energy: Potential and Future Prospects. Renew. Sustain. Energy Rev. 2018, 82, 894-900. [CrossRef]

30. Chala, G.T.; Ma'Arof, M.I.N.; Sharma, R. Trends in an Increased Dependence towards Hydropower Energy Utilization-A Short Review. Cogent Eng. 2019, 6, 1-14. [CrossRef]

31. Kaunda, C.S.; Kimambo, C.Z.; Nielsen, T.K. Hydropower in the Context of Sustainable Energy Supply: A Review of Technologies and Challenges. ISRN Renew. Energy 2012, 2012, 730631. [CrossRef]

32. Llamosas, C.; Sovacool, B.K. The Future of Hydropower? A Systematic Review of the Drivers, Benefits and Governance Dynamics of Transboundary Dams. Renew. Sustain. Energy Rev. 2021, 137, 110495. [CrossRef]

33. Kubiszewski, I.; Costanza, R.; Paquet, P.; Halimi, S. Hydropower Development in the Lower Mekong Basin: Alternative Approaches to Deal with Uncertainty. Reg. Environ. Chang. 2013, 13, 3-15. [CrossRef]

34. Sood, A.; Mathukumalli, B.K.P. Managing International River Basins: Reviewing India-Bangladesh Transboundary Water Issues. Int. J. River Basin Manag. 2011, 9, 43-52. [CrossRef]

35. Schmalensee, R. The Future of Solar Energy: A Personal Assessment. Energy Econ. 2015, 52, 142-148. [CrossRef]

36. International Energy Agency. Renewables 2019: Analysis and Forecast to 2024; International Energy Agency: Paris, France, 2019.

37. Fan, K.; Nam, S. Accelerating Geothermal Development in Indonesia: A Case Study in the Underutilization of Geothermal Energy. Consilience 2018, 19, 103-129. [CrossRef]

38. International Energy Agency. Ocean Power 2020. Available online: https://www.iea.org/reports/ocean-power (accessed on 6 May 2021). 
39. Afolalu, S.A.; Yusuf, O.O.; Abioye, A.A.; Emetere, M.E.; Ongbali, S.O.; Samuel, O.D. Biofuel; A Sustainable Renewable Source of Energy-A Review. IOP Conf. Ser. Earth Environ. Sci. 2021, 665, 012040. [CrossRef]

40. OECD; Food and Agriculture Organization of the United Nations. OECD-FAO Agricultural Outlook 2020-2029; OECD: Paris, France, 2020; ISBN 9-7892-6431-7673.

41. Republic of Indonesia. Government Regulations Number 79 Year 2014 Concerning National Energy Policy; Republic of Indonesia: Jakarta, Indonesia, 2014.

42. IESR. Indonesia Clean Energy Outlook: Tracking Progress and Review of Clean Energy Development in Indonesia; Institute for Essential Services Reform: Jakarta, Indonesia, 2019.

43. Ministry of Energy and Mineral Resources of the Republic of Indonesia. Mandatory biodiesel 30\% Program (B30); 2019. Available online: http:/ /ebtke.esdm.go.id/post/2019/12/19/2434/faq.program.mandatori.biodiesel.30.b30langen (accessed on 10 April 2020).

44. Manik, Y.; Halog, A. A Meta-Analytic Review of Life Cycle Assessment and Flow Analyses Studies of Palm Oil Biodiesel. Integr. Environ. Assess. Manag. 2013, 9, 134-141. [CrossRef]

45. Hall, C.A.S.; Lambert, J.G.; Balogh, S.B. EROI of Different Fuels and the Implications for Society. Energy Policy 2014, 64, 141-152. [CrossRef]

46. Capellán-Pérez, I.; de Castro, C.; Miguel González, L.J. Dynamic Energy Return on Energy Investment (EROI) and Material Requirements in Scenarios of Global Transition to Renewable Energies. Energy Strategy Rev. 2019, 26, 100399. [CrossRef]

47. Papong, S.; Chom-In, T.; Noksa-nga, S.; Malakul, P. Life Cycle Energy Efficiency and Potentials of Biodiesel Production from Palm Oil in Thailand. Energy Policy 2010, 38, 226-233. [CrossRef]

48. Kamahara, H.; Hasanudin, U.; Widiyanto, A.; Tachibana, R.; Atsuta, Y.; Goto, N.; Daimon, H.; Fujie, K. Improvement Potential for Net Energy Balance of Biodiesel Derived from Palm Oil: A Case Study from Indonesian Practice. Biomass Bioenergy 2010, 34 , 1818-1824. [CrossRef]

49. Sheehan, J.; Camobreco, V.; Duffield, J.; Graboski, M.; Graboski, M.; Shapouri, H. Life Cycle Inventory of Biodiesel and Petroleum Diesel for Use in an Urban Bus; National Renewable Energy Laboratory: Golden, CO, USA, 1998.

50. Carraretto, C. Biodiesel as Alternative Fuel: Experimental Analysis and Energetic Evaluations. Energy 2004, $29,2195-2211$. [CrossRef]

51. Pimentel, D.; Patzek, T.W. Ethanol Production Using Corn, Switchgrass, and Wood; Biodiesel Production Using Soybean and Sunflower. Nat. Resour. Res. 2005, 14, 65-76. [CrossRef]

52. Hill, J.; Nelson, E.; Tilman, D.; Polasky, S.; Tiffany, D. Environmental, Economic, and Energetic Costs and Benefits of Biodiesel and Ethanol Biofuels. Proc. Natl. Acad. Sci. USA 2006, 103, 11206-11210. [CrossRef]

53. Tsoutsos, T.; Kouloumpis, V.; Zafiris, T.; Foteinis, S. Life Cycle Assessment for Biodiesel Production under Greek Climate Conditions. J. Clean. Prod. 2010, 18, 328-335. [CrossRef]

54. Cavalett, O.; Ortega, E. Integrated Environmental Assessment of Biodiesel Production from Soybean in Brazil. J. Clean. Prod. 2010, 18, 55-70. [CrossRef]

55. Pradhan, A.; Shrestha, D.S.; McAloon, A.; Yee, W.; Haas, M.; Duffield, J.A. Energy Life-Cycle Assessment of Soybean Biodiesel Revisited. Trans. ASABE 2011, 54, 1031-1039. [CrossRef]

56. Rocha, M.H.; Capaz, R.S.; Lora, E.E.S.; Nogueira, L.A.H.; Leme, M.M.V.; Renó, M.L.G.; del Olmo, O.A. Life Cycle Assessment (LCA) for Biofuels in Brazilian Conditions: A Meta-Analysis. Renew. Sustain. Energy Rev. 2014, 37, 435-459. [CrossRef]

57. Brondani, M.; Hoffmann, R.; Mayer, F.D.; Kleinert, J.S. Environmental and Energy Analysis of Biodiesel Production in Rio Grande Do Sul, Brazil. Clean Technol. Environ. Policy 2015, 17, 129-143. [CrossRef]

58. Piastrellini, R.; Arena, A.P.; Civit, B. Energy Life-Cycle Analysis of Soybean Biodiesel: Effects of Tillage and Water Management. Energy 2017, 126, 13-20. [CrossRef]

59. Lorrenz, D.; Morris, D. How Much Energy Does It Take to Make A Gallon of Ethanol? Revisited and Updated; Institute for Local Self-Reliance: Minneapolis, MN, USA, 1995.

60. Yusoff, S.; Hansen, S.B. Feasibility Study of Performing an Life Cycle Assessment on Crude Palm Oil Production in Malaysia (9 Pp). Int. J. Life Cycle Assess. 2007, 12, 50-58. [CrossRef]

61. Thamsiriroj, T.; Murphy, J.D. Is It Better to Import Palm Oil from Thailand to Produce Biodiesel in Ireland than to Produce Biodiesel from Indigenous Irish Rape Seed? Appl. Energy 2009, 86, 595-604. [CrossRef]

62. Yee, K.F.; Tan, K.T.; Abdullah, A.Z.; Lee, K.T. Life Cycle Assessment of Palm Biodiesel: Revealing Facts and Benefits for Sustainability. Appl. Energy 2009, 86, 189-196. [CrossRef]

63. Pleanjai, S.; Gheewala, S.H. Full Chain Energy Analysis of Biodiesel Production from Palm Oil in Thailand. Appl. Energy 2009, 86, 209-214. [CrossRef]

64. Angarita, E.E.Y.; Lora, E.E.S.; da Costa, R.E.; Torres, E.A. The Energy Balance in the Palm Oil-Derived Methyl Ester (PME) Life Cycle for the Cases in Brazil and Colombia. Renew. Energy 2009, 34, 2905-2913. [CrossRef]

65. Lam, M.K.; Lee, K.T.; Mohamed, A.R. Life Cycle Assessment for the Production of Biodiesel: A Case Study in Malaysia for Palm Oil versus Jatropha Oil. Biofuels Bioprod. Bioref. 2009, 3, 601-612. [CrossRef]

66. Achten, W.M.J.; Vandenbempt, P.; Almeida, J.; Mathijs, E.; Muys, B. Life Cycle Assessment of a Palm Oil System with Simultaneous Production of Biodiesel and Cooking Oil in Cameroon. Environ. Sci. Technol. 2010, 44, 4809-4815. [CrossRef] [PubMed] 
67. De Souza, S.P.; Pacca, S.; de Ávila, M.T.; Borges, J.L.B. Greenhouse Gas Emissions and Energy Balance of Palm Oil Biofuel. Renew. Energy 2010, 35, 2552-2561. [CrossRef]

68. Queiroz, A.G.; França, L.; Ponte, M.X. The Life Cycle Assessment of Biodiesel from Palm Oil ("Dendê") in the Amazon. Biomass Bioenergy 2012, 36, 50-59. [CrossRef]

69. Agostinho, F.; Siche, R. Hidden Costs of a Typical Embodied Energy Analysis: Brazilian Sugarcane Ethanol as a Case Study. Biomass Bioenergy 2014, 71, 69-83. [CrossRef]

70. Khatiwada, D.; Venkata, B.K.; Silveira, S.; Johnson, F.X. Energy and GHG Balances of Ethanol Production from Cane Molasses in Indonesia. Appl. Energy 2016, 164, 756-768. [CrossRef]

71. Atlason, R.S.; Lehtinen, T.; Davíðsdóttir, B.; Gísladóttir, G.; Brocza, F.; Unnpórsson, R.; Ragnarsdóttir, K.V. Energy Return on Investment of Austrian Sugar Beet: A Small-Scale Comparison between Organic and Conventional Production. Biomass Bioenergy 2015, 75, 267-271. [CrossRef]

72. Saga, K.; Imou, K.; Yokoyama, S.; Minowa, T. Net Energy Analysis of Bioethanol Production System from High-Yield Rice Plant in Japan. Appl. Energy 2010, 87, 2164-2168. [CrossRef]

73. Prueksakorn, K.; Gheewala, S.H. Full Chain Energy Analysis of Biodiesel from Jatropha curcas L. in Thailand. Environ. Sci. Technol. 2008, 42, 3388-3393. [CrossRef]

74. Ooi, L.-H.; Heriansyah, H. Palm Pulverisation in Sustainable Oil Palm Replanting. Plant Prod. Sci. 2005, 8, 345-348. [CrossRef]

75. Purnomo, H.; Okarda, B.; Dermawan, A.; Ilham, Q.P.; Pacheco, P.; Nurfatriani, F.; Suhendang, E. Reconciling Oil Palm Economic Development and Environmental Conservation in Indonesia: A Value Chain Dynamic Approach. Forest Policy Econ. 2020, 111, 1-12. [CrossRef]

76. Jong, H.N. Indonesia Fires Emitted Double the Carbon of Amazon Fires, Research Shows: Mongabay Environmental News. 2019. Available online: https://news.mongabay.com/2019/11/indonesia-fires-amazon-carbon-emissions-peatland/ (accessed on 27 September 2020).

77. Pichler, M.; Brad, A. Political Ecology and Socio-Ecological Conflicts in Southeast Asia. Austrian J. South East Asian Stud. 2016, 9 , 1-10. [CrossRef]

78. Afriyanti, D.; Kroeze, C.; Saad, A. Indonesia Palm Oil Production without Deforestation and Peat Conversion by 2050. Sci. Total Environ. 2016, 557-558, 562-570. [CrossRef]

79. Walmsley, T.G.; Walmsley, M.R.W.; Atkins, M.J. Energy Return on Energy and Carbon Investment of Wind Energy Farms: A Case Study of New Zealand. J. Clean. Prod. 2017, 167, 885-895. [CrossRef]

80. Walmsley, T.G.; Walmsley, M.R.W.; Varbanov, P.S.; Klemeš, J.J. Energy Ratio Analysis and Accounting for Renewable and Non-Renewable Electricity Generation: A Review. Renew. Sustain. Energy Rev. 2018, 98, 328-345. [CrossRef]

81. Bhandari, K.P.; Collier, J.M.; Ellingson, R.J.; Apul, D.S. Energy Payback Time (EPBT) and Energy Return on Energy Invested (EROI) of Solar Photovoltaic Systems: A Systematic Review and Meta-Analysis. Renew. Sustain. Energy Rev. 2015, 47, 133-141. [CrossRef]

82. Atlason, R.S.; Unnthorsson, R. Hot Water Production Improves the Energy Return on Investment of Geothermal Power Plants. Energy 2013, 51, 273-280. [CrossRef]

83. Lambert, J.G.; Hall, C.A.S.; Balogh, S.; Gupta, A.; Arnold, M. Energy, EROI and Quality of Life. Energy Policy 2014, 64, 153-167. [CrossRef]

84. Fizaine, F.; Court, V. Energy Expenditure, Economic Growth, and the Minimum EROI of Society. Energy Policy 2016, 95, 172-186. [CrossRef]

85. Indonesian Palm Oil Association. The Strategic Role of the Indonesian People's Oil Palm. 2018. Available online: https: //gapki.id/news/3875/peran-strategis-sawit-rakyat-indonesia (accessed on 10 June 2020).

86. Bureau of Statistics of Indonesia. Indonesian Oil Palm Statistics 2018; Bureau of Statistics of Indonesia: Jakarta, Indonesia, 2018.

87. Shubik, M. The Dollar Auction Game: A Paradox in Noncooperative Behavior and Escalation. J. Confl. Resolut. 1971, 15, 109-111. [CrossRef]

88. Suharyati; Pambudi, S.H.; Wibowo, J.L.; Pratiwi, N.I. Indonesia Energy Outlook 2019; National Energy Council: Jakarta, Indonesia, 2019. Available online: https://www.esdm.go.id/assets/media/content/content-indonesia-energy-outlook-2019-englishversion.pdf (accessed on 24 June 2020).

89. Saleh, S.; Bagja, B.; Putra, S.; Said, Z.; Putraditama, A.; Widyapratami, H. Smallholders Oil Palm Plantation Intensification: Where Do We Start? Working Paper; World Resources Institute Indonesia: Jakarta, Indonesia, 2019.

90. Cheong, K.H.; Ngiam, N.J.; Morgan, G.G.; Pek, P.P.; Tan, B.Y.; Lai, J.W.; Koh, J.M.; Ong, M.E.H.; Ho, A.F.W. Acute Health Impacts of the Southeast Asian Transboundary Haze Problem-A Review. Int. J. Environ. Res. Public Health 2019, 16, 3286. [CrossRef]

91. Hu, Y.; Fernandez-Anez, N.; Smith, T.E.L.; Rein, G. Review of Emissions from Smouldering Peat Fires and Their Contribution to Regional Haze Episodes. Int. J. Wildland Fire 2018, 27, 293-312. [CrossRef]

92. Jahirul, M.; Rasul, M.; Chowdhury, A.; Ashwath, N. Biofuels Production through Biomass Pyrolysis-A Technological Review. Energies 2012, 5, 4952-5001. [CrossRef]

93. Osman, A.I.; Hefny, M.; Abdel Maksoud, M.I.A.; Elgarahy, A.M.; Rooney, D.W. Recent Advances in Carbon Capture Storage and Utilisation Technologies: A Review. Environ. Chem. Lett. 2021, 19, 797-849. [CrossRef]

94. Babin, A.; Vaneeckhaute, C.; Iliuta, M.C. Potential and Challenges of Bioenergy with Carbon Capture and Storage as a CarbonNegative Energy Source: A Review. Biomass Bioenergy 2021, 146, 105968. [CrossRef] 